\title{
APPLICATION OF WATER EQUIVALENTS METHOD TO CALCULATION OF RADIATION RECUPERATORS WITH MICROFINNED SURFACE
}

\section{NOTATION:}

$\alpha_{c}-$ convection heat-transfer coefficient of furnace gas, $\mathrm{W} /\left(\mathrm{m}^{2} \cdot \mathrm{K}\right)$

$\alpha-$ convection heat-transfer coefficient (microfinned element), $\mathrm{W} /\left(\mathrm{m}^{2} \cdot \mathrm{K}\right.$ )

$\alpha_{g}-$ heat-transfer coefficient of furnace gas, $\mathrm{W} /\left(\mathrm{m}^{2} \cdot \mathrm{K}\right)$

$\mathrm{c}_{a}$ - heat capacity of air, $\mathrm{kJ} /\left(\mathrm{m}^{3} \cdot \mathrm{K}\right)$

$\mathrm{c}_{g}$ - heat capacity of furnace gas, $\mathrm{kJ} /\left(\mathrm{m}^{3} \cdot \mathrm{K}\right)$

$D, d$ - equivalent diameter, $\mathrm{m}$

$F$ - heating surface area, $\mathrm{m}^{2}$

$H$ - height of recuperator, $\mathrm{m}$

$h$ - height of micro-fin, $\mathrm{m}$

$l$ - distance between axes of micro-fines, $\mathrm{m}$

$r$ - equivalent radius, $\mathrm{m}$

$s$ - thickness, $\mathrm{m}$

$k$ - over-all heat-transfer coefficient, $\mathrm{W} /\left(\mathrm{m}^{2} \cdot \mathrm{K}\right)$

$\Delta p$ - pressure, $\mathrm{Pa}$

$T_{g}, t_{g}$ - temperature of furnace gas, $\mathrm{K},{ }^{\circ} \mathrm{C}$

* Ph.D., Faculty of Metals Engineering and Industrial Computer Science, AGH University of Science and Technology, Cracow, Poland; ztcos@agh.edu.pl 


$$
\begin{aligned}
& T_{w}, t_{w}-\text { wall temperature, } \mathrm{K},{ }^{\circ} \mathrm{C} \\
& T_{a}, t_{a}-\text { temperature of air, } \mathrm{K},{ }^{\circ} \mathrm{C} \\
& \mathrm{Re}-\text { Reynolds Number } \\
& \mathrm{N}-\text { Number of Heat Transfer Units } \\
& Q-\text { heat transfer rate, } \mathrm{W} \\
& q-\text { heat flux, } \mathrm{W} / \mathrm{m}^{2} \\
& V-\text { volumetric rate of fluid flow, } \mathrm{m}^{3} / \mathrm{s} \\
& W_{a}-\text { water equivalent of air, } \mathrm{W} / \mathrm{K} \\
& W_{g}-\text { water equivalent of furnace gas, } \mathrm{W} / \mathrm{K} \\
& w-\text { velocity, m/s } \\
& \eta-\text { dynamic viscosity factor, }(\mathrm{kg} \cdot \mathrm{m}) / \mathrm{s} \\
& \lambda-\text { number of hydraulic resistance }(\mathrm{microfinned} \mathrm{element)} \\
& \rho-\text { density, kg/m }{ }^{3} \\
& \mathrm{Y}-\text { intensification function. }
\end{aligned}
$$

\section{INTRODUCTION}

Radiation recuperators are used for the recovery of heat from waste gases with industrial heat furnaces, glass furnaces and foundry ones $[1-3,5-7,9,12,13]$. The radiation recuperators work in range temperatures $700^{\circ} \mathrm{C} \div 1500^{\circ} \mathrm{C}$. For calculation of this recuperators zonal model [8], single-zone model [11] and universal method of calculation [10] were elaborated. In these models were applied the results of research on convective heat-transfer coefficients and numbers hydraulic resistance of microfinned recuperator elements. In calculation of heat exchangers the water equivalents method is very important $[6,9,12,14]$. This method is more universal than balance method. The aim of this paper is mathematic algorithm by water equivalents method to calculation of radiation recuperators with microfinned surface and application in this algorithm the model researches.

\section{SIMILARITY FUNCTION USED TO CALCULATE THE HEATING SURFACE OF PARALLEL-FLOW RECUPERATORS}

Radiation recuperators with microfinned surface belong to parallel-flow heat exchangers group. The water equivalent method enable to calculate the construction parameters of heat exchangers. In recuperators recovered furnace gas from industrial furnaces water equivalent of furnace gas is

$$
W_{g}=V_{g} c_{g}
$$


where:

$V_{g}$ - volumetric rate of furnace gas flow,

$c_{g}$ - heat capacity of furnace gas.

Water equivalent of air is

$$
W_{a}=V_{a} c_{a}
$$

where:

$V_{a}$ - volumetric rate of air,

$c_{a}-$ heat capacity of air.

Water equivalent of furnace gas is greater than air water equivalent

$$
W_{g}>W_{a}
$$

The similarity function is expressed by equation

$$
\begin{aligned}
& \theta=f\left(\frac{W_{a}}{W_{g}}, \mathrm{~N}\right) \\
& \theta=\frac{t_{a}^{\prime \prime}-t_{a}^{\prime}}{t_{g}^{\prime}-t_{a}^{\prime}}
\end{aligned}
$$

where:

$t_{a}^{\prime \prime}$ - air preheated temperature outlet,

$t_{a}^{\prime}$ - air temperature inlet to recuperator,

$t_{g}^{\prime}$ - furnace gas temperature inlet to recuperator,

$\mathrm{N}$ - Number of Heat Transfer Units.

The Number of Heat Transfer Units is the measure of heat surface area and is expressed by equation

$$
\mathrm{N}=\frac{k F}{W_{a}}
$$

where:

$k$ - over-all heat transfer coefficient,

$F$ - heat transfer surface area,

$W_{a}$ - water equivalent of air. 
Similarity function by equation (4) illustrates Figure 1 and Figure 2.

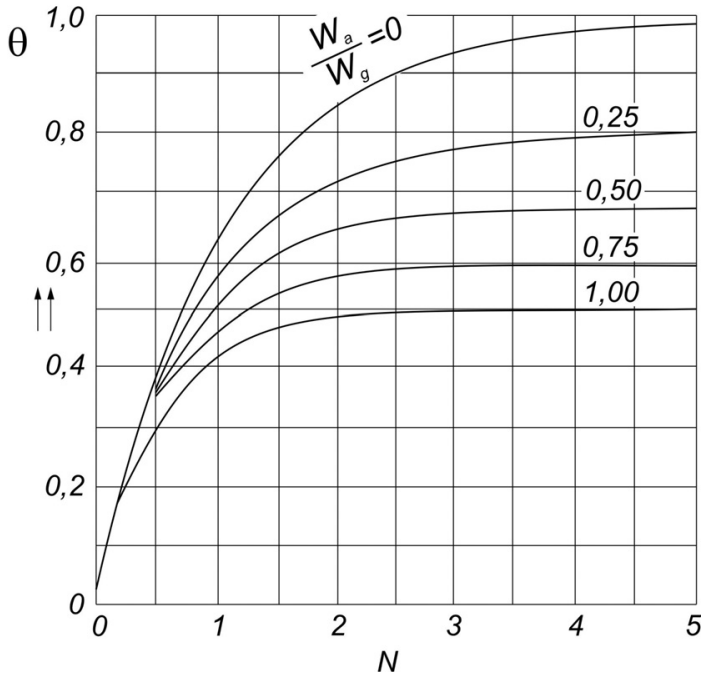

Fig. 1. Similarity function $\theta=f\left(\frac{W_{a}}{W_{g}}, \mathrm{~N}\right)$

used in parallel-flow heat exchangers [9, 15]

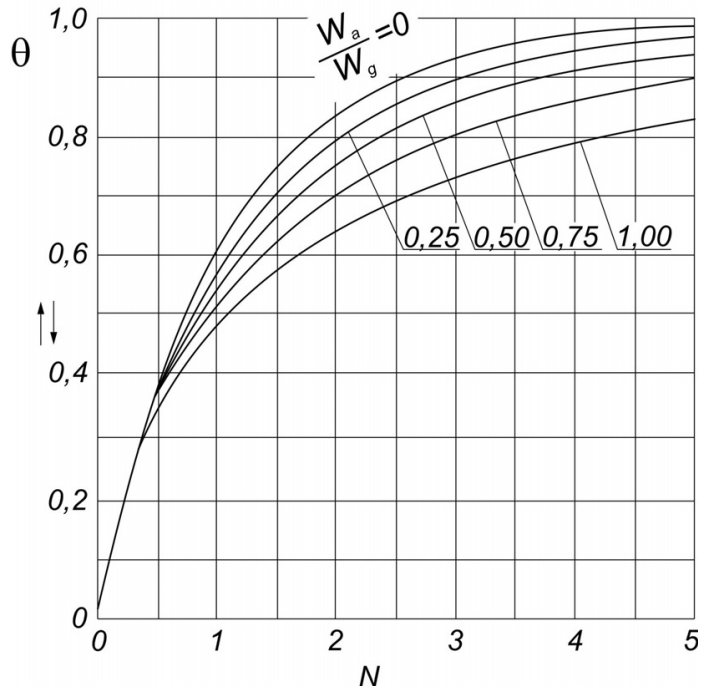

Fig. 2. Similarity function $\theta=f\left(\frac{W_{a}}{W_{g}}, \mathrm{~N}\right)$ used in counter-flow heat exchangers [9, 15] 


\section{THE CALCULATIONS OF RADIATION RECUPERATORS WITH MICROFINNED SURFACE BY WATER EQUIVALENT METHOD}

The proposed algorithm of calculation of radiation recuperators with microfinned surface algorithm consist of:

- equations by water equivalents method,

- similarity equations by model researches (9), (11), (20), (21),

- equations verifying value of over-all heat-transfer coefficient $(12 \div 19)$.

The microfinned surface area of recuperator is

$$
F=\frac{\mathrm{N} W_{a}}{k}
$$

where:

$\mathrm{N}$ - Number of Heat Transfer Units,

$W_{a}$ - water equivalent of air,

$k$ - over-all heat transfer coefficient.

The water equivalent of air is

$$
W_{a}=V_{a} c_{a},
$$

where:

$V_{a}$ - volumetric rate of air flow,

$c_{a}-$ heat capacity of air.

The height of recuperator is

$$
H=\frac{F}{\Pi d_{o}}
$$

where $d_{o}-$ outer diameter of center tube.

The convective heat-transfer coefficient to air (microfinned element) is

$$
\alpha=(1+\mathrm{Y})\left(3.5 t+0.00174 \bar{t}_{a}\right) \frac{w_{a}^{0.8}}{\left(D-d_{o}\right)^{0.2}}
$$

where:

$\mathrm{Y}$ - intensification function,

$w_{a}$ - velocity of air,

$D$ - diameter of inner cover,

$d_{o}$ - outer diameter of center tube. 
The symbol $t_{a}$ denotes air arithmetic mean temperature

$$
t_{a}=\frac{t_{a}^{\prime}+t_{a}^{\prime \prime}}{2}
$$

The intensification function is

$$
\mathrm{Y}=36.52\left(\frac{l}{h}\right)^{0.35} e^{-0.037 \frac{l}{h}} \mathrm{Re}^{-0.36}
$$

$4000 \leq \operatorname{Re} \leq 12000$

$5 \leq \frac{l}{h} \leq 40$

$h>h_{r}>0$.

where:

$l$ - micro-fin pitch,

$h$ - height of micro-fin,

$h_{r}$ - height of roughhes.

The heat-transfer coefficient of furnace gas is given by equation:

$$
\alpha_{g}=\frac{1}{\frac{1}{k}-\frac{1}{\alpha}}
$$

The weighted mean temperature of microfinned center tube is

$$
t_{w}=\frac{\alpha_{g} \bar{t}_{g}+\alpha \overline{t_{a}}}{\alpha_{g}+\alpha}
$$

The symbol $\overline{t_{g}}$ denotes arithmetic mean temperature of furnace gas

$$
\begin{aligned}
& \bar{t}_{g}=\frac{t_{g}^{\prime}+t_{g}^{\prime \prime}}{2} \\
& t_{g}^{\prime \prime}=t_{g}^{\prime} \frac{c_{g}^{\prime}}{c_{g}^{\prime \prime}}-\frac{V_{a} c_{a}\left(t_{a}^{\prime \prime}-t_{a}^{\prime}\right)}{\xi V_{g} c_{g}^{\prime}}
\end{aligned}
$$


where:

$V_{a}$ - volumetric rate of air flow,

$c_{a}$ - heat capacity of air,

$V_{g}$ - volumetric rate of furnace gas flow,

$c_{g}^{\prime}, c_{g}^{\prime \prime}-$ heat capacity of furnace gas,

$\xi-$ number of losses,

$t_{g}^{\prime}$ - furnace gas temperature inlet to recuperator,

$t_{a}^{\prime \prime}$ - air preheated temperature outlet,

$t_{a}^{\prime}-$ air temperature inlet.

The heat transfer rate is

$$
Q_{a}=V_{a} c_{a}\left(t_{a}^{\prime \prime}-t_{a}^{\prime}\right)
$$

where:

$V_{a}$ - volumetric rate of air flow,

$c_{a}$ - heat capacity of air,

$t_{a}^{\prime \prime}$ - air preheat temperature outlet,

$t_{a}^{\prime}$ - air temperature inlet.

The heat flux through recuperator wall is

$q=\frac{Q_{a}}{F}$

The heat-transfer coefficient of furnace gas is

$\alpha_{g}=\frac{q}{\overline{t_{g}}-\bar{t}_{w}}$

The over-all heat-transfer coefficient is

$$
k=\frac{1}{\frac{1}{\alpha_{p}}+\frac{1}{\alpha}}
$$

The pressure drop of air is $[1,6]$

$$
\Delta p_{a}=\lambda \frac{w_{a}^{2} \rho_{a}}{2} \frac{H}{D-d_{i}}
$$




$$
\begin{aligned}
& \lambda=0.316\left(\frac{r}{h}\right)^{-0.76}\left(\frac{l}{h}\right)^{0.56} e^{-0.061 \frac{l}{h}} \\
& 2.67 \leq \frac{r}{h} \leq 16,5 \leq \frac{l}{h} \leq 40, h>h_{r}>0 .
\end{aligned}
$$

\section{THE CALCULATIONS OF RADIATION RECUPERATOR WITH MICROFINNED SURFACE TO HEAT FURNACE}

The parallel flow radiation recuperator with microfinned surface is installed in heat furnace. The recuperator is determined by the following conditions:

- volumetric rate of furnace gas flow

$$
\begin{aligned}
V_{g} & =1130 \mathrm{~m}^{3} / \mathrm{h}\left(0.314 \mathrm{~m}^{3} / \mathrm{s}\right) \\
t_{g}^{\prime} & =1250^{\circ} \mathrm{C} \\
V_{a}^{\prime} & =1030 \mathrm{~m}^{3} / \mathrm{h}\left(0.286 \mathrm{~m}^{3} / \mathrm{s}\right) \\
t_{a}^{\prime \prime} & =500^{\circ} \mathrm{C} \\
d_{i} & =1.00 \mathrm{~m} \\
s & =0.005 \mathrm{~m} \\
d_{o} & =1.01 \mathrm{~m} \\
D & =1.05 \mathrm{~m}
\end{aligned}
$$

The air water equivalent is

$$
\begin{aligned}
& W_{a}=V_{a} c_{a}=0.286 \cdot 1330=380 \mathrm{~W} / \mathrm{K}, \\
& c_{a}=1330 \mathrm{~J} /\left(\mathrm{m}^{3} \cdot \mathrm{K}\right) .
\end{aligned}
$$

The furnace gas water equivalent is

$$
\begin{aligned}
& W_{g}=V_{g} \cdot c_{g}=0.314 \cdot 1640=510 \mathrm{~W} / \mathrm{K}, \\
& c_{g}=1640 \mathrm{~J} /\left(\mathrm{m}^{3} \cdot \mathrm{K}\right) .
\end{aligned}
$$

The simplex of water equivalent is

$$
\frac{W_{a}}{W_{g}}=\frac{380}{510}=0.75 \text {. }
$$

The temperature simplex is expressed by equation

$$
\varepsilon=\frac{t_{a}^{\prime \prime}-t_{a}^{\prime}}{t_{g}^{\prime}-t_{a}^{\prime}}=\frac{500-20}{1250-20}=0.40
$$


The Number of Heat Transfer Units by Figure 1 is 0.60 .

The over-all heat-transfer coefficient is $33 \mathrm{~W} /\left(\mathrm{m}^{2} \cdot \mathrm{K}\right)$.

The microfinned surface area of recuperator is

$$
F=\frac{\mathrm{N} W_{a}}{k}=\frac{0.6 \cdot 380}{33}=6.91 / \mathrm{m}^{2} .
$$

The height of recuperator is

$$
H=\frac{F}{\Pi d_{o}}=\frac{6.91}{\Pi \cdot 1.00}=2.20 \mathrm{~m} .
$$

The air mean temperature is

$$
\bar{t}_{a}=\frac{t_{a}^{\prime \prime}+t_{a}^{\prime}}{2}=\frac{500+20}{2}=260^{\circ} \mathrm{C} .
$$

The velocity of air is

$$
w_{a}=\frac{V_{a}}{\frac{\Pi}{4}\left(D^{2}-d_{o}^{2}\right)}=\frac{0.286}{\frac{\Pi}{4}\left(1.05^{2}-1.01^{2}\right)}=4.4 \mathrm{~m} / \mathrm{s} .
$$

The equivalent diameter of air gap is

$d_{h}=D-d_{o}=1.05-1.01=0.04 \mathrm{~m}$.

The convection heat-transfer coefficient (smooth center tube) to air equals

$$
\alpha_{o}=\left(3.57+0.00174 \overline{t_{a}}\right) \frac{w_{a}^{0.8}}{d_{h}^{0.2}}=(3.57+0.00174 \cdot 260) \frac{4.4^{0.8}}{0.04^{0.2}}=24.8 \mathrm{~W} /\left(\mathrm{m}^{2} \cdot \mathrm{K}\right)
$$

The Reynolds number in air gap is

$$
\operatorname{Re}=\frac{w_{a} \cdot d_{h} \rho_{o}}{\eta}=\frac{4.4 \cdot 0.04 \cdot 1.27}{27.04 \cdot 10^{-6}}=8266,
$$

where:

$w_{a}=4.4 \mathrm{~m} / \mathrm{s}-$ velocity of air,

$\rho_{\mathrm{o}}=1.27 \mathrm{~kg} / \mathrm{m}^{3}-$ density of air,

$p_{o}=1000 \mathrm{hPa}$,

$T_{o}=273 \mathrm{~K}$,

$d_{h}=0.04 \mathrm{~m}-$ hydraulic diameter,

$\eta=27.04 \cdot 10^{-6}(\mathrm{~kg} \cdot \mathrm{m}) / \mathrm{s}-$ dynamic viscosity factor. 
The intensification function is

$$
\mathrm{Y}=36.52\left(\frac{l}{h}\right)^{0.35} e^{-0.037 \frac{l}{h}} \mathrm{Re}^{-0.36}=36.52 \cdot 10^{0.35} e^{-0.037 \cdot 10} 8266^{-0.36}=2.19 .
$$

The heat-transfer coefficient of microfinned center tube is

$\alpha=(1+\mathrm{Y}) \alpha_{o}=(1+2.19) \cdot 24.8=79.1 \mathrm{~W} /\left(\mathrm{m}^{2} \cdot \mathrm{K}\right)$.

The heat-transfer coefficient of furnace gas is

$$
\alpha_{g}=\frac{1}{\frac{1}{k}-\frac{1}{\alpha}}=\frac{1}{\frac{1}{33}-\frac{1}{79.1}}=56.5 \mathrm{~W} /\left(\mathrm{m}^{2} \cdot \mathrm{K}\right)
$$

The furnace gas temperature outlet from recuperator is

$$
t_{g}^{\prime \prime}=t_{g}^{\prime} \frac{c_{g}^{\prime}}{c_{g}^{\prime \prime}}-\frac{V_{a} c_{a}\left(t_{a}^{\prime \prime}-t_{a}^{\prime}\right)}{\xi V_{g} c_{g}^{\prime \prime}}=1250 \frac{1.64}{1.55}-\frac{0.286 \cdot 1.33 \cdot 480}{0.9 \cdot 0.314 \cdot 1.55}=906^{\mathrm{o}} \mathrm{C}
$$

where:

$$
\begin{aligned}
t_{g}^{\prime \prime}=1250^{\circ} \mathrm{C}- & \text { furnace gas temperature inlet to recupe- } \\
& \text { rator, }
\end{aligned}
$$

$c_{g}^{\prime}=1.64 \mathrm{~kJ} /\left(\mathrm{m}^{3} \cdot \mathrm{K}\right), c_{g}^{\prime \prime}=1.55 \mathrm{~kJ} /\left(\mathrm{m}^{3} \cdot \mathrm{K}\right)$ - heat capacity of furnace gas,

$t_{a}^{\prime}=20^{\circ} \mathrm{C}-$ air temperature inlet,

$t_{a}^{\prime \prime}=500^{\circ} \mathrm{C}-$ air preheat temperature outlet,

$c_{a}=1.33 \mathrm{~kJ} /\left(\mathrm{m}^{3} \cdot \mathrm{K}\right)$ - heat capacity of air,

$\xi=0.9-$ number of losses.

The furnace gas mean temperature is

$$
\bar{t}_{g}=\frac{1250+906}{2}=1078^{\circ} \mathrm{C} \text {. }
$$

The weighted mean temperature of microfinned center tube is

$$
\begin{aligned}
& \bar{t}_{w}=\frac{\alpha_{g} \bar{t}_{g}+\alpha \bar{t}_{a}}{\alpha_{g}+\alpha}, \\
& \bar{t}_{w}=\frac{56.5 \cdot 1078+79.1 \cdot 260}{56.5+79.1}=602^{\circ} \mathrm{C} .
\end{aligned}
$$


The heat transfer rate is

$$
Q_{a}=V_{a} c_{a}\left(t_{a}^{\prime \prime}-t_{a}^{\prime}\right)=0.286 \cdot 1330 \cdot(500-20)=182582 \mathrm{~W} \text {. }
$$

The heat flux through recuperator wall is

$q=\frac{Q_{a}}{F}=\frac{182582}{6.91}=26423 \mathrm{~W} / \mathrm{m}^{2}$.

The heat-transfer coefficient of furnace gas is

$$
\alpha_{g}=\frac{q}{\bar{t}_{g}-\bar{t}_{w}}=\frac{26423}{1078-602}=55.5 \mathrm{~W} /\left(\mathrm{m}^{2} \cdot \mathrm{K}\right) \text {. }
$$

The over-all heat-transfer coefficient is

$$
k=\frac{1}{\frac{1}{\alpha_{g}}+\frac{1}{\alpha}}=\frac{1}{\frac{1}{55.5}+\frac{1}{79.1}}=32.5 \mathrm{~W} /\left(\mathrm{m}^{2} \cdot \mathrm{K}\right) .
$$

The error calculation of over-all heat-transfer coefficient is $\Delta=1.5 \%$.

The radiation recuperator with microfinned surface illustrates Figure 3.

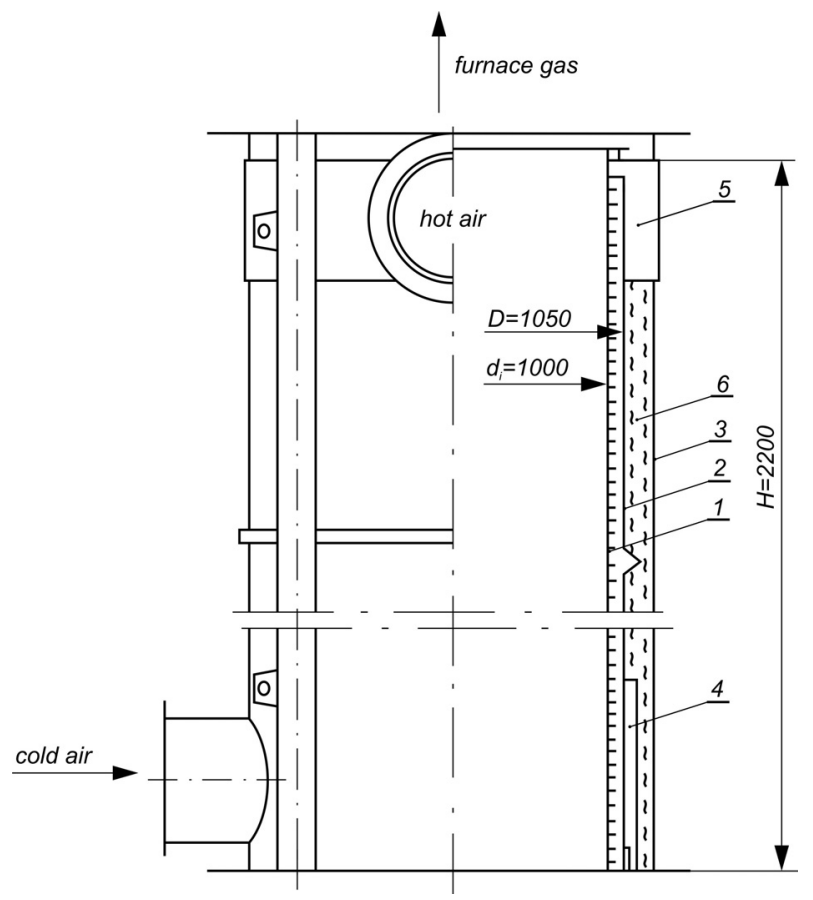

Fig. 3. Radiation recuperator: 1 - microfinned center tube, 2 -inner cover, 3 -outer cover, 4 -inlet chamber, 5 - outlet chamber, 6 - heat insulation 
The number of hydraulic resistance in air channel is

$$
\lambda=0.316\left(\frac{r}{h}\right)^{-0.76}\left(\frac{l}{h}\right)^{-0.56} e^{-0.061 \frac{l}{h}}=0.316\left(\frac{0.02}{0.004}\right)^{-0.76} 10^{-0.56} e^{-0.061 \cdot 10}=0.18
$$

where:

$r=0.02 \mathrm{~m}-$ equivalent hydraulic radius,

$h=0.004 \mathrm{~m}-$ height of micro-fin,

$l=0.04-$ micro-fin pitch.

The pressure drop of air is

$$
\Delta p_{a}=\lambda \frac{w_{a}^{2} \rho_{a}}{2} \frac{H}{D-d_{o}}=0.18 \frac{4 \cdot 4^{2} \cdot 1.27}{2} \cdot \frac{2.2}{1.05-1.01}=121.7 \mathrm{~Pa}
$$

\section{INFERENCES}

- Water equivalents method has a great importance in calculation of heat exchangers.

- The algorithm elaborated to calculations of radiation recuperators with microfinned surface consists of: equation by water equivalents method, similarity equations and control ones.

- The results of research on convective heat-transfer coefficients and numbers hydraulic resistance of microfinned elements for ranges were applied in the algorithm:

$$
4200<\operatorname{Re}<12000, \quad 5<\frac{l}{h}<40, \quad 2.67<\frac{r}{h}<16, \quad h>h_{r}>0 .
$$

- This new algorithm made possible the projects of radiation recuperator with microfinned surface to glass furnaces and heat furnaces.

The work was made in contract no. 11.11.110.865.

\section{REFERENCES}

[1] Karczewski K.: Zeszyty naukowe AGH, Metalurgia i odlewnictwo, 16 (1990), 133

[2] Karczewski K.: Hutnik, 58 (1991), 172 $\div 174$

[3] Karczewski K.: Radiation Recuperators with Microfinned Surface. Int. Symp. Technical University of Kosice, 1994

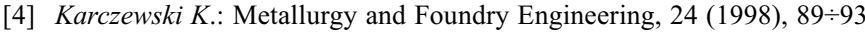

[5] Karczewski K.: Metallic Recuperators to Glass Tanks. Technical University of Kosice, Kosice, 1998

[6] Karczewski K.: Wpływ mikroużebrowania powierzchni równoległoprądowych rekuperatorów metalowych na ich cechy konstrukcyjne i eksploatacyjne. UWND AGH, Kraków, 2000 
[7] Karczewski K.: Metallurgy and Foundry Engineering, 29 (2003), 97 $\div 107$

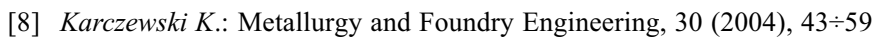

[9] Karczewski K.: Obliczenia cieplne rekuperatorów metalowych dla pieców przemysłowych. UWND AGH, Kraków, 2004, SU 1667

[10] Karczewski K.: Metallurgy and Foundry Engineering, 31 (2005), 185 $\div 200$

[11] Karczewski K.: Metallurgy and Foundry Engineering, 33 (2007), 129 $\div 139$

[12] Mikheyev M.: Fundamentals of Heat Transfer, Moscow 1968, Mir Publishers

[13] Seo K., Kim V.: Int. J. Heat and Mass Transfer, 43 (2000), 2869-2882

[14] Szargut J., Ziębik A., Kozioł J., Majza E.: Przemysłowa energia odpadowa. Zasady wykorzystania. Urządzenia. WNT, Warszawa, 1993

[15] Tajc N.: Raszczety nagrewatielnych pieczej. Moskwa, 1969

Received

October 2008 